\title{
ANALISIS TINGKAT KINERJA, TINGKAT KEPENTINGAN DAN TINGKAT KESESUAIAN BAURAN PEMASARAN YAKULT DI KOTA PONTIANAK
}

\author{
Andry Lindi Lim \\ email: Vaynard_northgard@yahoo.com \\ Fakultas Ekonomi dan Bisnis Universitas Widya Dharma Pontianak
}

\begin{abstract}
Abstrak
Penelitian ini bertujuan untuk mengetahui kebijakan pemasaran yang diteliti, meliputi produk (product), harga (price), saluran distribusi (place), promosi (promotion) terhadap minuman Yakult, dan tanggapan responden atas penjualan Yakult dan tanggapan terhadap penjualan retailer yang menjual produk pada konsumen akhir. dan penulis membatasinya pada Analisis Tingkat Kepentingan, Tingkat Kinerja dan Tingkat Kesesuaian Bauran Pemasaran Yakult di Kota Pontianak. Metode deskriptif dan teknik pengumpulan data dilakukan dengan melakukan wawancara, studi dokumenter dan kuesioner. Populasinya adalah para konsumen langsung. Teknik pengambilan sampel dari populasi menggunakan purposive sampling dengan 100 responden. Hasil penelitian menunjukkan hasil sangat sesuai. Hasil perhitungan adalah: Produk (product) dengan nilai tingkat kesesuaian sebesar 97,24 persen, harga (price) dengan nilai tingkat kesesuaian sebesar 99,23 persen, saluran distribusi (place) dengan nilai tingkat kesesuaian sebesar 98,73 persen dan promosi (promotion) dengan nilai tingkat kesesuaian sebesar 98,57 persen. Tingkat kinerja kepentingan harga (price) kebijakan menempati peringkat pertama, kebijakan saluran distribusi (place) menempati peringkat kedua, Promosi (promotion) menempati peringkat ketiga, kebijakan produk menempati peringkat keempat. Saran-saran mencakup: Tingkatkan media sosial, dengan pemberian penghargaan atau hadiah kepada pengecer yang dapat menjual produk dalam jumlah banyak, dan melakukan inovasi produk dengan menambah rasa yang beragam untuk meningkatkan jumlah konsumen.
\end{abstract}

Kata-kata kunci: Analisis konsumen akhir

\begin{abstract}
This study aims to determine the marketing policies studied, including products, prices, distribution channels (place), promotion of Yakult drinks, and respondents' responses to Yakult sales and responses to retailer sales who sell products at the end consumer. and the authors limit it to the Analysis of the Level of Interest, Level of Performance and Suitability of the Yakult Marketing Mix in Pontianak City. Descriptive methods and data collection techniques were carried out by conducting interviews, documentary studies and questionnaires. The population is direct consumers. The sampling technique of the population used purposive sampling with 100 respondents. The results showed that the results were very suitable. The results of the calculation are: a product with a conformity level value of 97.24 percent, a price with a conformity level value of 99.23 percent, a distribution channel (place) with a conformity level value of 98.73 percent and a promotion. ) with a conformity level value of 98.57 percent. The level of performance of the interest in price policy was ranked first, distribution channel policy (place) was ranked second, promotion was ranked third, product policy was ranked fourth. Suggestions include: Increase social media, by giving awards or gifts to retailers who can sell a large number of products, and innovating products by adding a variety of flavors to increase the number of consumers.
\end{abstract}

Key words: End user analysis 


\section{A. Pendahuluan}

Yakult idalah minuman susu fermentasi yang mengandung Lactobacillus casei yang dapat menuju usus dalam kondisi hidup. Satu botol minuman Yakult diklaim berguna untuk membantu menjaga kesehatan pencernaan serta menekan pertumbuhan bakteri yang tidak bermanfaat di dalam sistem pencernaan manusia. Beberapa manfaat minuman Yakult antara lain: Menjaga keseimbangan mikroorganisme baik di dalam usus, menekan pertumbuhan bakteri merugikan, mengurangi racun di dalam tubuh, mencegah gangguan pencernaan seperti sembelit atau diare, dan meningkatkan kualitas kekebalan tubuh.

Yakult dibuat dari bahan baku seperti air, sukrosa, susu bubuk skim, perisa identik alam, dan kultur bakteri asam laktat (Lactobacillus casei Shirota strain). Untuk menghasilkan produk yang aman dengan kualitas terbaik, menerapkan proses produksi berdasarkan manajemen keamanan pangan sesuai standar ISO 22000:2005. Selain itu, pabrik juga menggunakan mesin otomatis dan sistem tertutup, yang merupakan standar bagi seluruh pabrik, selain seluruh perlengkapan produksi menggunakan bahan stainless steel terbaik dan berkualitas. Berbeda dengan produk minuman sejenis, Yakult memang hanya dikemas dalam botol berukuran mini, sekitar $65 \mathrm{ml}$, dan tidak tersedia dalam kemasan ukuran botol air mineral. Karena dengan ukuran $65 \mathrm{ml}$, produk ini telah memuat lebih dari 6,5 miliar bakteri Lactobacillus casei Shirota strain yang berguna bagi tubuh. Di samping itu, dengan kemasan yang mini, diharapkan dapat diminum dalam sekali waktu atau satu tegukan sehingga meminimalkan terjadinya kontaminasi silang dari luar ke dalam produk. Untuk kebutuhan ini, tutup botol didesain menggunakan bahan aluminium foil agar bisa langsung dihabiskan dalam sekali

waktu.

(Panca, 2000).

Seiring dengan pertumbuhan penduduk perkembangan di bidang-bidang kehidupan manusia menjadi sangat kompleks khususnya untuk perkembangan ilmu pengetahuan, pendidikan dan teknologi yang diikuti oleh perkembangan bidang-bidang lainnya seperti ekonomi, sosial dan budaya akan berpengaruh terhadap kehidupan masyarakat. Kondisi tersebut dikarenakan terjadinya peningkatan yang cukup berarti terhadap kebutuhan prasarana dan sarana bagi masyarakat. Dengan semakin meningkatnya pengetahuan, kebutuhan dan kepedulian masyarakat terhadap kesehatan menyebabkan semakin berkembangnya perusahaanperusahaan yang mencoba untuk menawarkan barang atau jasa sejenis sehingga menyebabkan terjadinya persaingan yang sangat ketat di antara perusahaan-perusahaan dalam merebut pangsa pasar. Perusahaan yang berorientasi kepada pasar harus memikirkan cara mempengaruhi konsumen agar membeli produknya, khususnya pembeli potensial agar bersedia membeli produk yang dihasilkan. Untuk dapat bertahan dalam keadaan pasar yang peka terhadap perubahan yang memiliki persaingan saat ini, sebuah perusahaan pertama-tama harus menentukan barang atau jasa apa yang dapat dijual dan kebijakan apa yang mendukung dalam meningkatkan konsumen baru dan mempertahankan pelanggan lama.

Dalam usaha memperoleh laba sebesar-besarnya yang dilakukan perusahaan melalui peningkatan volume penjualan, perusahaan berusaha menetapkan kebijakan pemasaran yang tepat dalam memasarkan produk. Untuk menetapkan kebijakan pemasaran yang tepat, perusahaan harus memiliki informasi yang tepat mengenai kapan, mengapa, di mana produk tersebut dibutuhkan, serta siapa saja yang membutuhkan produk tersebut. Hal ini dilakukan agar produk yang dipasarkan sesuai dengan sasaran dan tujuan perusahaan. Pada umumnya perusahaan menerapkan atau melaksanakan bauran pemasaran (marketing mix) secara terpadu agar dapat meningkatkan volume penjualan barangnya di samping kepuasan konsumen dapat terpenuhi. Yakult merupakan satu dari produk minuman susu fermentasi, yang dibuat dengan cara memfermentasi susu bubuk skim yang mengandung bakteri asam laktat hidup Lactobacillus casei Shirota strain. Yakult menghadapi persaingan dari perusahaan minuman lainnya. Oleh karena itu, perusahaan harus menetapkan harga dengan baik dan cocok yang 
didukung oleh elemen-elemen bauran pemasaran yang lain, supaya dapat menghadapi persaingan dan dapat meningkatkan tingkat penjualan secara baik.

Dalam perkembangannnya, perusahaan harus berusaha untuk menyesuaikan diri dengan perkembangan pasar demi menjamin keberlangsungan hidup perusahaan. Untuk menjalankan kegiatan bisnis, perusahaan juga harus berfokus dengan perubahan dan perkembangan selera konsumen, yaitu dengan melakukan inovasi terhadap produk yang dihasilkan, serta menjaga hubungan baik dengan konsumen yang ada. Faktor internal perusahaan juga harus menjadi perhatian penting dari manajemen perusahaan. Manajemen perusahaan harus mengawasi kegiatan dari setiap bagian perusahaan agar seluruh tugas yang ada bisa dikerjakan dengan cepat dan tepat. Aspek usaha merupakan salah satu kegiatan perusahaan yang menyatakan bahwa pemasaran merupakan syarat utama bagi kelangsungan hidup perusahaan. Perusahaan dapat dikatakan berhasil mencapai tujuan jangka pendek, apabila perusahaan tersebut berhasil memasarkan produknya. Keberhasilan dalam memasarkan produk sangat dipengaruhi oleh kemampuan perusahaan dalam mengelola dan menetapkan kebijakan pemasaran yang tepat sehingga produk yang ditawarkan dapat bersaing dengan produk merek lain yang sejenis.

Aspek pemasaran adalah suatu proses sosial yang memberikan kepada individu dan kelompok apa yang mereka butuhkan dan inginkan dengan menciptakan dan mempertukarkan produk-produk dan nilai dengan individu dan kelompok lain. Dengan pemasaran perusahaan dapat menciptakan hubungan, menjaga dan memperoleh respon dari pasar perusahaan. Perusahaan tidak hanya memasarkan produknya saja tetapi juga perlu menjaga hubungan baik dengan pelanggan, dengan begitu perusahaan akan mempunyai nilai yang baik di mata pelanggannya. Dengan menjaga hubungan baik dengan pelanggan, perusahaan dapat memperoleh keuntungan yang lebih besar.

Kini banyak perusahaan yang menyadari arti pentingnya pemasaran dalam menjalankan bisnisnya untuk memperoleh apa yang ingin dicapai oleh perusahaan. Tujuan-tujuan pemasaran yang dilakukan hendaknya sejalan dengan tujuan perusahaan yang ingin dicapai baik dalam jangka pendek maupun jangka panjang. Bila pemasaran tidak berhasil, maka tujuan perusahaan tidak akan terwujud seperti yang direncanakan. Pemasaran merupakan salah satu aktivitas yang penting bagi perusahaan, karena setiap perusahaan bila ingin berkembang dan terus berkembang tidak dapat melepaskan diri dari pemasaran. Pemasaran merupakan salah satu kegiatan pokok untuk perkembangan dan mendapatkan laba. Kegiatan pemasaran perusahaan harus dapat juga memberikan kepuasan kepada pemakai jika menginginkan usahanya berjalan terus. Dalam menghadapi persaingan yang semakin ketat dan agar para konsumen mempunyai pandangan yang baik terhadap produk dari perusahaan maka perusahaan menerapkan kebijakan pemasaran yaitu berupa peningkatan pelayanan dari segi produk, harga, distribusi dan promosi kepada pelanggan. Kebijakan pemasaran perlu untuk dikelola dan terus dikembangkan agar menjadi lebih baik sehingga mampu sesuai di dengan konsumen.

Perusahaan melakukan kebijakan pemasaran untuk membuat konsumen membeli produk yang mereka tawarkan. Promosi meupakan salah satu aspek penting dalam manajemen pemasaran. Promosi yang dilakukan bertujuan untuk meningkatkan volume penjualan perusahaan. Promosi berguna untuk memberitahu, membujuk dan mengimbas keputusan pembelian konsekuen. Kegiatan promosi yang dilaksanakan ditujukan untuk mempertahankan laba penjualan yang telah dicapai. Promosi yang telah dijalankan perusahaan ini yaitu melalui mulut ke mulut, ke toko-toko dan melalui iklan ditelevisi. Bentuk promosi yang digunakan biasanya adalah edukasi mengenai manfaat produk Yakult. Pesaing utama yakult adalah dari sesama produk susu fermentasi.

Dalam memasarkan Yakult, melakukan kegiatan penyaluran produk ke berbagai daerah, baik dalam kota yang meliputi Kota Pontianak maupun luar Kota Pontianak. Sebagian besar daerah pemasaran Yakult berpusat pada daerah Kota Pontianak yang merupakan daerah pangsa pasar yang terbesar dan berpotensi untuk melakukan pemasaran. Untuk daerah pemasaran luar 
kota dapat ditempuh dengan transportasi darat yang dimiliki perusahaan, maka kegiatan pemasaran produk Yakult dilakukan secara bertahap berdasarkan wilayah pemasarannya. Untuk menunjang kegiatan pemasaran produk-produk Yakult, transportasi atau pengangkutan merupakan bagian yang sangat penting sebagai sarana untuk memindahkan barang secara fisik dari satu tempat ke tempat lain. Transportasi sangat penting perannya karena merupakan kunci dalam memperlancar arus barang dari perusahaan ke penyalur kemudian ke konsumen.

Sarana transportasi merupakan salah satu faktor penunjang kegiatan pemasaran. Sarana transportasi harus dipilih secara tepat agar dapat memberikan tingkat efisiensi yang tinggi bagi perusahaan dari segi biaya, kecepatan dan keamanan. Sarana transportasi atau pengangkutan yang tersedia dimaksudkan untuk menunjang kegiatan pemasaran produk-produknya, mengatur dan memantau barang-barang dagangan supaya bisa cepat menjangkau daerah-daerah pemasaran yang telah dan yang akan ditentukan.

Sistem pemasaran Yakult terdiri dari dua jenis:

1. Sistem Direct Sales

Sistem ini digunakan untuk mendistribusikan Yakult ke toko, supermarket, minimarket, dan lain-lain. Distribusi dilakukan menggunakan mobil berpendingin.

2. Sistem Yakult Lady

Melalui sistem ini didistribusikan oleh ibu-ibu rumah tangga kepada masyarakat di lingkungan tempat tinggal mereka. Ketika melayani masyarakat, Yakult Lady juga melakukan penjelasan mengenai manfaat Yakult.

Berikut ini adalah Tabel 1 volume penjualan Yakult di Kota Pontianak:

Tabel 1. Volume Penjualan Yakult di Kota Pontianak (2015-2019)

\begin{tabular}{cccc}
\hline Tahun & Botol/65 ml & $\begin{array}{c}\text { Penjualan } \\
(\mathbf{R p})\end{array}$ & $\Delta$ Pertumbuhan Botol (\%) \\
\hline 2015 & 8.700 .000 & $18.270 .000 .000,00$ & - \\
2016 & 8.900 .000 & $18.690 .000 .000,00$ & 2,30 \\
2017 & 9.300 .000 & $19.530 .000 .000,00$ & 4,49 \\
2018 & 9.500 .000 & $20.900 .000 .000,00$ & 2,15 \\
2019 & 9.800 .000 & $21.560 .000 .000,00$ & 3,16 \\
\hline
\end{tabular}

Sumber: Data olahan, 2020

Peneliti membatasi permasalahan pada:

1. Kebijakan pemasaran yang diteliti, meliputi produk (product), harga (price), saluran distribusi (place), promosi (promotion) terhadap minuman Yakult.

2. Tanggapan responden atas penjualan Yakult dan tanggapan terhadap pengecer yang menjual produk pada konsumen akhir.

\section{B. Kajian Teori}

Marketing adalah proses di mana seseorang atau kelompok dapat memenuhi need dan want melalui penciptaan, penawaran dan pertukaran barang atau jasa". (Alma, 2011). Konsep bersaing yang dijadikan sebagai pedoman oleh perusahaan untuk melakukan kegiatan pemasaran adalah:

1. Konsep produksi,

2. Konsep produk,

3. Konsep penjualan,

4. Konsep pemasaran, dan

5. Konsep pemasaran masyarakat. (Kotler, 2005). 
Pengertian marketing oleh para ahli dikemukakan berbeda-beda dalam penyajian dan penekanannya, tetapi semua itu sebenarnya mempunyai pengertian yang hampir sama antara satu sama lainnya. "Pemasaran adalah satu fungsi organisasi dan seperangkat proses untuk menciptakan, mengkomunikasikan dan menyerahkan nilai kepada pelanggan dan mengelola hubungan pelanggan dengan cara yang menguntungkan organisasi dan para pemilik sahamnya". (Kotler dan Keller, 2008). "Pemasaran merupakan proses manajemen yang berupaya memaksimumkan laba (returns) bagi pemegang saham, dengan jalan menjalin relasi dengan pelanggan utama (valued customers) dan menciptakan keunggulan kompetitif'. Salah satu konsep utama dalam pemasaran modern adalah bauran pemasaran (marketing mix). (Doyle yang dikutip oleh Tjiptono, 2005). "Bauran pemasaran (marketing mix) adalah seperangkat alat pemasaran yang digunakan perusahaan untuk terus menerus mencapai tujuan pemasarannya di pasar sasaran”. (Kotler, 2005). Unsur-unsur bauran pemasaran:

\section{Produk (Product)}

"Produk adalah segala sesuatu yang dapat ditawarkan ke pasar untuk mendapatkan perhatian, dibeli, digunakan, atau dikonsumsi yang dapat memuaskan keinginan atau kebutuhan." (Kotler dan Armstrong, 2001). Jenis-jenis barang konsumsi dibagi menjadi beberapa macam:
a) Barang konveniens (Convenience Goods),
b) Barang belanja (Shopping Goods),
c) Produk khusus (Specialty Products), dan
d) Barang yang tidak dicari (Unsought Goods). (Boyd, Walker, dan Larreche, 2000).

\section{Harga (Price)}

"Harga adalah sejumlah kompensasi (uang maupun barang, kalau mungkin) yang dibutuhkan untuk mendapatkan sejumlah kombinasi barang atau jasa." (Fuad, et al (2000): "Harga adalah sejumlah uang yang dibebankan atas suatu barang atau jasa, atau jumlah dari nilai yang ditukar konsumen atas manfaat-manfaat karena memiliki atau menggunakan produk atau jasa tersebut.” (Kolter dan Armstrong, 2001)

\section{Saluran Distribusi (Place)}

"Saluran distribusi adalah saluran yang digunakan oleh produsen untuk menyalurkan produk sampai ke konsumen atau berbagai aktivitas perusahaan yang mengupayakan agar produk sampai ke tangan konsumen". (Fuad, et al, 2000). "Fungsi saluran distribusi adalah memindahkan barang dan jasa dari produsen ke konsumen, pemindahan itu mengatasi kesenjangan waktu, tempat dan kepemilikan yang memisahkan barang dan jasa dari mereka yang akan mempergunakannya". ( Kotler dan Armstrong, 2001).

Terdapat empat tingkatan saluran:

a) Saluran pemasaran langsung, terdiri dari satu perusahaan yang menjual langsung ke konsumen.

b) Saluran pemasaran tidak langsung berisi satu perantara penjualan, seperti pengecer.

c) Saluran dua tingkatan perantara berisi pedagang besar dan pengecer

d) Saluran tiga tingkatan perantara berisi pedagang besar, pemborong, dan pengecer. (Kotler dan Armstrong, 2001).

\section{Promosi (promotion)}

"Promosi adalah arus informasi atau persuasi satu arah yang dibuat untuk mengarahkan seseorang atau organisasi kepada tindakan yang menciptakan pertukaran di dalam pemasaran". Jadi promosi merupakan fungsi pemberitahuan, pembujukan dan pengimbasan keputusan 
pembelian konsekuen. Dalam promosi terjadi proses penyajian pesan-pesan yang ditujukan untuk membantu penjualan barang dan jasa. Promosi merupakan aktifitas pemasaran yang mungkin paling kontroversial yang secara rutin dilaksanakan oleh perusahaan. Yang termasuk dalam kegiatan promosi adalah sebagai berikut: periklanan, personal selling, promosi penjualan dan publisitas. (Dharmmestha dan Irawan, 2008):

a) Ada empat jenis promosi yaitu:

b) Iklan (Advertising),

c) Promosi penjualan (Sales Promotion),

d) Penjualan personal (Personal Selling), dan

e) Publisitas (Publicity). (Peter dan Olson, 2000),

\section{Metode Penelitian}

"Penelitian deskriptif adalah penelitian yang berpola menggambarkan apa yang ada di lapangan dan mengupayakan penggambaran ata, terlepas apakah data itu kualitatif ataupun kuantitatif". (Sudjarwo, 2001). "Observasi adalah teknik pengumpulan data yang dilakukan melalui suatu pengamatan, dengan disertai pencatatan-pencatatan terhadap keadaan atau perilaku objek sasaran". (Fathoni, 2006). "Wawancara digunakan sebagai teknik pengumpulan data apabila peneliti ingin melakukan studi pendahuluan untuk menemukan permasalahan yang harus diteliti, dan juga apabila peneliti ingin mengetahui hal-hal dari responden yang lebih mendalam dan jumlah respondennya sedikit/kecil”. (Sugiyono, 2012).

TABEL 2. Variabel Dan Indikator Penelitian

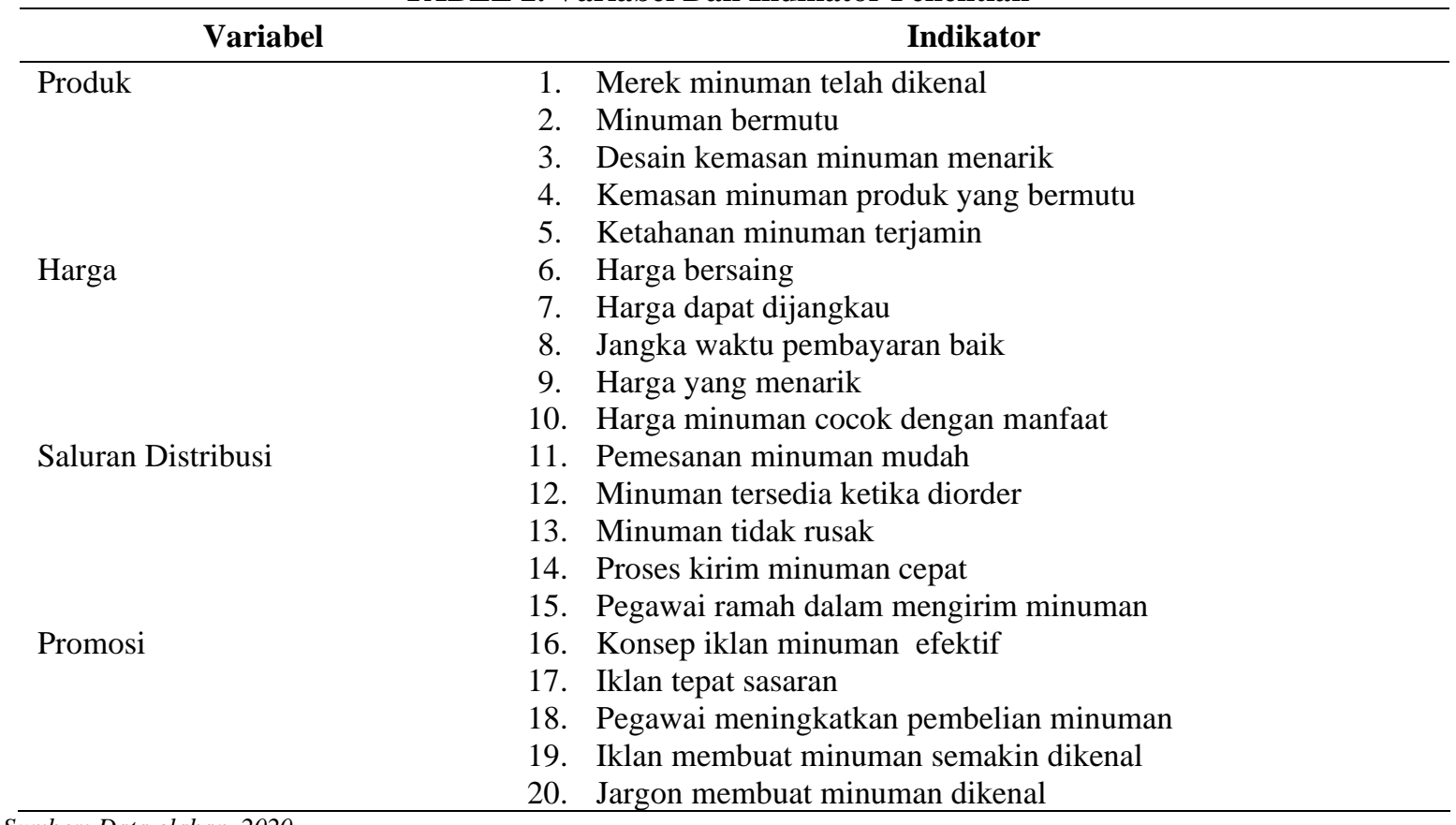

Sumber: Data olahan, 2020

"Kuesioner adalah sejumlah pertanyaan tertulis yang digunakan untuk memperoleh informasi dari responden dalam arti laporan tentang pribadinya, atau hal-hal yang ia ketahui". Yang menjadi populasi dalam penelitian ini adalah seluruh konsumen akhir Yakult di Kota Pontianak. Pemilihan sampel dilakukan dengan metode purposive sampling, yaitu sampel yang dipilih secara sengaja untuk mewakili populasi berdasarkan ciri-ciri khusus yaitu pelanggan yang berlangganan Yakult minimal satu tahun dan berlokasi di Kota Pontianak sebanyak seratus responden. Sesuai dengan tujuan penelitian, untuk mengetahui pelaksanaan dari kebijakan perusahaan dan seberapa besar pengaruhnya terhadap kepuasan konsumen, teknik analisis data yang digunakan adalah teknik analisis kualitatif. (Arikunto (2006). "Analisis 
kualitatif merupakan analisis yang mendasar pada adanya hubungan semantis antara variabel yang sedang diteliti." (Sarwono, 2006).

\section{Hasil Analisis Data Penelitian dan Pembahasan}

\section{Analisis Kebijakan Pemasaran}

Persaingan yang ketat dalam dunia bisnis menuntut Pengecer untuk semakin jeli dalam membuat perencanaan pemasaran yang baik, agar tujuan perusahaan dapat tercapai. Setiap perusahaan memiliki tujuan yang sama, yaitu untuk mencapai laba yang maksimal, tetapi masing-masing perusahaan selalu memiliki kebijakan yang berbeda dalam mencapai tujuannya. Banyak faktor yang mempengaruhi keberhasilan suatu bisnis antara lain: Kebijakan yang tepat, karyawan yang berdedikasi, sistem informasi yang bagus dan implementasi yang bagus.

Dalam pemasaran modern pengecer selain memberikan saran-saran mengenai pengembangan produk yang baik, penetapan harga yang bersaing dan menyediakan produk bagi para pelanggan sasaran, perusahaan haruslah berkomunikasi dengan pelanggannya. Aspek ini dikerjakan agar perusahaan dapat mengetahui dan memuaskan kebutuhan pelanggan serta apa yang dikemukakan jangan sampai menyebabkan keraguan dari pelanggan. Berkembangnya aktivitas ekonomi, gaya hidup dan aktivitas masyarakat menyebabkan perubahan selera masyarakat dalam mengkonsumsi produk. Hal ini menjadi tantangan bagi Pengecer. Kebijakan tersebut, meliputi produk (product), harga (price), distribusi (place) dan promosi (promotion). Kebijakan perusahaan seluruhnya difokuskan pada kepuasan pelanggan dengan cara menyesuaikan produk dengan selera, kebutuhan dan keinginan pelanggan. Jika konsumen merasa puas terhadap perusahaan, maka konsumen akan cenderung loyal kepada perusahaan, sehingga kelangsungan hidup perusahaan akan terjamin dan dapat berkembang.

Pengecer menetapkan beberapa kebijakan pemasaran, antara lain:

a) Kebijakan Produk

Pengecer berusaha agar konsumen tidak semata dalam membeli produknya saja, tetapi juga memperhatikan manfaat dari produk yang akan dibeli. Kebijakan produk merupakan salah satu faktor penting dalam menetapkan kebijakan pemasaran. Dalam menetapkan kebijakan produk, perusahaan perlu menyediakan produk yang tepat bagi konsumen, sehingga dapat memuaskan konsumen dan mendatangkan keuntungan bagi konsumen.

Pengecer mendistribusikan produk minuman Yakult untuk Kota Pontianak, tidak memiliki wewenang secara langsung untuk menetapkan kebijakan produk, namun Pengecer ini memiliki hak untuk memberikan masukan kepada pusatnya yang berada di Jakarta mengenai Yakult dan perusahaan juga bisa mempertahankan dan mengembangkan aspek produk dalam memasarkan produk. Minuman Yakult merupakan salah satu minuman prebiotik (minuman kesehatan) yang diproduksi dan didistribusikan oleh pengecer. Minuman Yakult berfungsi sebagai minuman prebiotik kesehatan untuk tubuh. Produk Yakult diproduksi dengan tujuan untuk melakukan pencegahan terhadap penyakit yaitu dengan menjaga tubuh. Dengan adanya minuman Yakult diharapkan agar kesehatan konsumen dapat terjaga. 


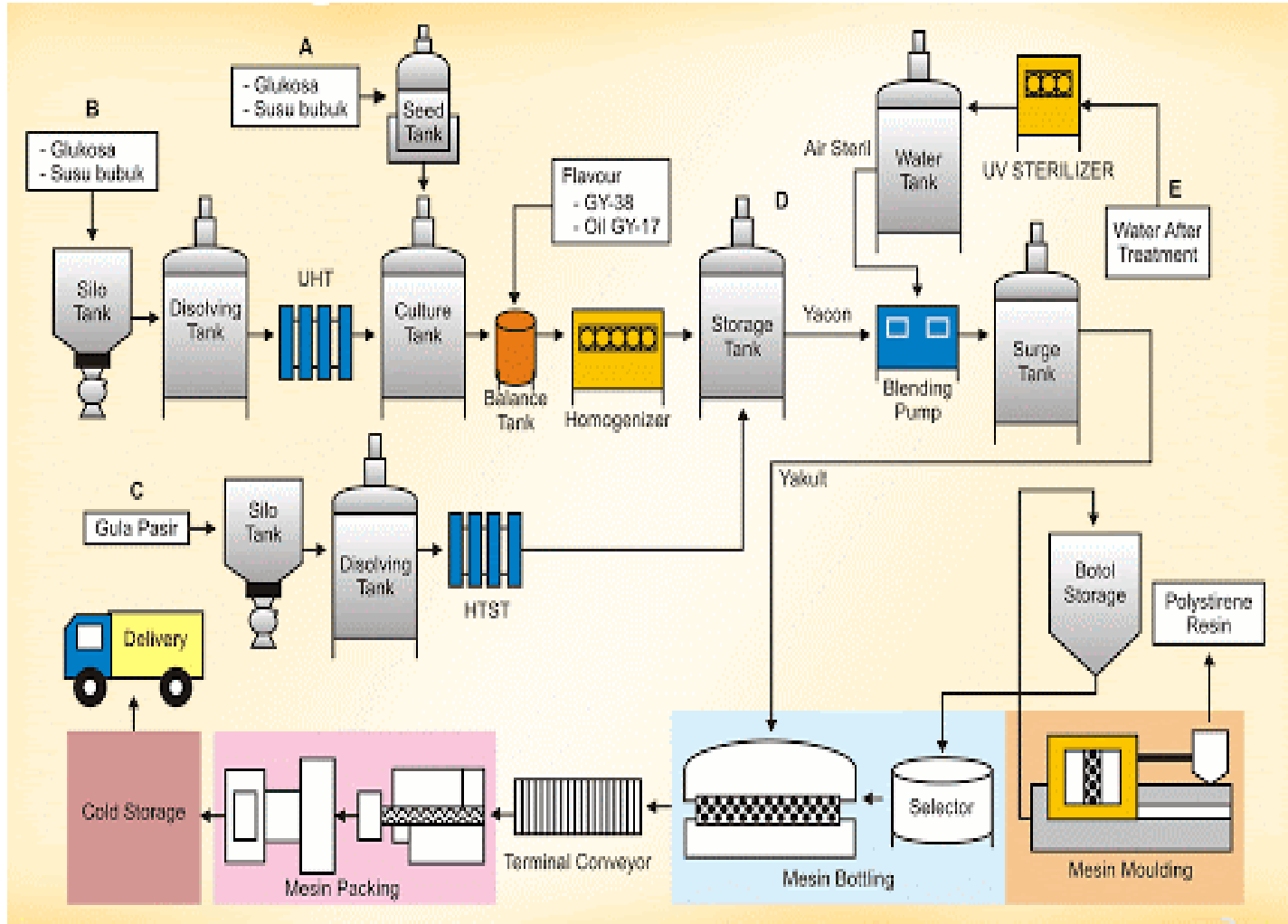

Sumber: Data olahan, 2020

Gambar 1. Proses Produksi Yakult

Dari proses-proses produksi tersebut bisa diketahui bahwa Yakult ini masuk ke dalam tipe proses produksi terus-menerus (continuous process) yang mana dalam prosesnya hanya menghasilkan satu produk minuman dari bahan mentah sampai dengan barang jadi dengan pola proses produksi yang berurutan sesuai dengan proses yang dijalankan, kegiatan ini akan berjalan terus menerus dalam jangka yang lama. Teknik proses produksi ini masuk ke dalam proses analitis di mana pada pembuatan minuman ini mencampur beberapa bahan mulai dari bahan yang satu dengan bahan yang lainnya karena adanya proses pencampuran bakteri sehingga menghasilkan suatu produk yang sudah sesuai dengan standarisasi dan tentu saja sehat. (http://erdyasyraf.blogspot.com/2018/11/sistem-produksi-pt.html)

b) Kebijakan Harga

Harga merupakan salah satu aspek penting yang ikut menentukan keberhasilan perusahaan dalam mecapai tujuan untuk memperoleh keuntungan sehingga dapat terus mempertahankan kelangsungan hidupnya. Harga juga merupakan satu-satunya bauran pemasaran yang memberikan pendapatan bagi perusahaan. Harga merupakan sejumlah nilai yang ditukarkan oleh pelanggan dengan manfaat yang dimiliki produk atau jasa yang nilainya telah disepakati oleh pihak penjual dan pembeli. Pengecer harus menerapkan kebijakan harga yang tepat sesuai dengan tingkat daya beli konsumen di mana akan mempengaruhi permintaan pasar dan secara langsung akan berpengaruh terhadap besar kecilnya keuntungan yang akan dicapai oleh perusahaan.

Setiap perusahaan harus menetapkan harga secara tepat agar mampu bersaing dengan perusahaan lainnya dalam memasarkan barang atau jasa. Penetapan kebijakan harga merupakan hal yang sulit, apabila perusahaan menetapkan harga jual rendah akan mempengaruhi volume pendapatan yang cenderung rendah, namun volume penjualan akan meningkat. Sebaliknya, jika perusahaan menetapkan harga jual yang lebih tinggi dari produk lain yang sejenis, maka volume penjualan akan semakin menurun. Harga jual minuman ditentukan secara terpusat baik harga ke pengecer maupun ke konsumen. Harga minuman ditawarkan sama baik kepada konsumen maupun pengecer dalam kondisi sama. Tidak susah mendapatkan produk Yakult, karena bisa 
dibeli di berbagai toko, swalayan, minimarket, dan situs online. Pembelian secara eceran, dengan harga Rp3.500 per botol. Sementara, apabila membeli per pack berisi 5 botol, harganya Rp10.000 - Rp11.500. Pembeli satu ball berisi 50 botol, ditetapkan harga berkisar Rp110.000. Sebagai perbandingan, pada 2020 lalu, kemasan eceran dijual dengan harga Rp3.000, sedangkan untuk kemasan pack isi 5 botol dijual dengan harga Rp8.500 - Rp9.500.

c) Kebijakan Saluran Distribusi

Dalam pemasaran modern saat ini, tugas perusahaan tidak hanya sekedar menghasilkan produk berkualitas dengan kemasan yang menarik, menentukan kebijakan harga yang menarik serta berkomunikasi secara efektif dengan para pelanggan. Akan tetapi, perusahaan juga dituntut untuk memikirkan cara yang efektif untuk mendistribusikan produknya serta menjamin ketersediaan produk di pasar sehingga pelanggan dapat dengan mudah menemukan produk yang mereka butuhkan. Sebagian besar produsen menggunakan perantara untuk menyalurkan produknya ke pasar. Mereka mencoba untuk membangun saluran distribusi agar produknya dapat tersebar ke berbagai daerah. Jalur distribusi Yakult dari pengecer sampai ke konsumen dapat dilihat pada Gambar 2:

Gambar 2. Jalur Distribusi Yakult

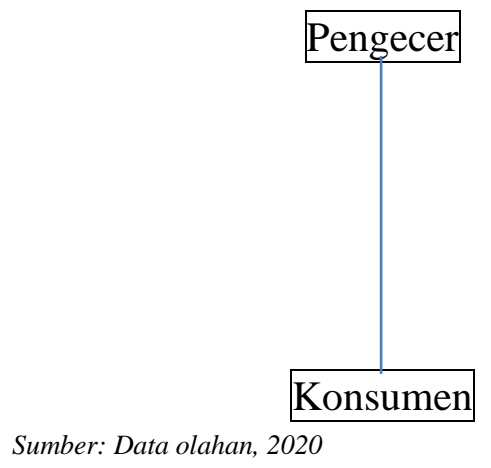

Dalam memasarkan minuman Yakult, digunakan sistem pemasaran multi-saluran. Luasnya daerah pemasaran tidak memungkinkan perusahaan untuk mendistribusikan produknya sendiri sehingga perusahaan juga menggunakan tenaga pengecer. Sistem ini dilakukan dengan tujuan agar perusahaan dapat menjangkau segmen-segmen pasar baik penjualan langsung maupun penjualan melalui retail. Dengan sistem ini, dapat dihemat biaya distribusi. melalui dua cara yaitu melalui pengecer dan distribusi langsung kepada konsumen akhir melalui Lady Yakult. Salah satu parameter utama keberhasilan kinerja sebuah perusahaan dalam melakukan distribusi adalah kualitas layanan pengantaran barang (delivery). Dalam melakukan pelayanan pengantaran barang, perusahaan memiliki mobil pengantaran. Beberapa hal yang dilakukan guna meningkatkan kualitas layanan pengantaran produk, antara lain:

Pengecer menetapkan standar kecepatan pengantaran paling lama dua puluh empat jam sejak produk dipesan.

Perusahaan menetapkan Standard Operating Procedure (SOP) yang baku untuk supir, baik standar pemeriksaan barang dan serah terimanya ke pengecer, pencatatan jam order dan jam kirim, penanganan komplain serta standar penerimaan dan penyelesaian retur barang. Standar ini ditetapkan untuk meminimalkan kesalahan pengiriman produk ke pengecer dan potensi kerugian bagi pengecer.

3) Perusahaan menetapkan pakaian dan tas dorong yang dikenakan oleh Lady Yakult, seragam yang dikenakan adalah kemeja berwarna putih dengan tulisan pada kemeja tersebut dan menggunakan celana kain.

d) Kebijakan Promosi 
Pemasar mengembangkan kebijakan promosi dengan tujuan untuk mengkomunikasikan informasi tentang produk mereka dan mempengaruhi konsumen untuk membeli. Kebijakan promosi merupakan salah satu faktor penting dalam memasarkan produk, karena penetapan kebijakan promosi sangat mempengaruhi tingkat penjualan perusahaan.

Kebijakan promosi yang telah ditetapkan oleh Yakult sebagai berikut:

1) Iklan

Iklan adalah penyajian informasi nonpersonal mengenai produk, merek, perusahaan atau toko yang dilakukan dengan bayaran tertentu. Yakult melaksanakan kegiatan periklanan guna menyampaikan informasi tentang minuman yang ditawarkan kepada konsumen dengan tujuan mempengaruhi konsumen agar tertarik untuk membeli. Dalam hal ini, media yang digunakan oleh perusahaan untuk mengiklankan Yakult, meliputi: televisi, baju kaos, mobil boks dan lainnya.

2) Promosi Penjualan

Promosi penjualan idalah rangsangan langsung yang diarahkan bagi konsumen guna melakukan pembelian. Yakult melakukan promosi penjualan dengan cara melakukan kebijakan satu harga agar tidak terjadi kebingungan bagi konsumen terhadap harga.

3) Penjualan Personal

Penjualan personal melibatkan interaksi personal langsung antara seorang pembeli potensial dengan seorang tenaga penjual. Dalam mendukung kinerja para pegawai, selalu ditanamkan sikap disiplin, sopan santun dan tanggung jawab kepada semua pegawai. Tujuannya agar pegawai dapat membina hubungan baik dengan semua konsumen akhir Yakult.

4) Publisitas

Publisitas ialah bentuk-bentuk komunikasi tentang perusahaan, produk atau merek yang tidak membutuhkan pembayaran. Dalam hal ini, produk minuman Yakult juga memiliki publisitas, yaitu terdapat artikel di media yang memberikan informasi mengenai reputasi perusahaan yang memproduksi, serta terdapat testimoni dari masyarakat mengenai di media internet.

\section{Analisis Tingkat Kinerja, Tingkat Kepentingan dan Tingkat Kesesuaian Bauran Pemasaran}

Tabel 3. Rata-Rata Tingkat Kinerja

Terhadap Variabel Kebijakan Pemasaran Yakult

\begin{tabular}{|c|c|c|}
\hline No. & Pertanyaan & $\begin{array}{c}\text { Rata-rata } \\
\text { Tingkat Kinerja }\end{array}$ \\
\hline A. & Produk & \\
\hline 1. & Merek minuman telah dikenal & 3,71 \\
\hline 2. & Minuman bermutu & 3,95 \\
\hline 3. & Desain kemasan minuman menarik & 3,92 \\
\hline 4. & Kemasan minuman produk yang bermutu & 3,82 \\
\hline 5. & Ketahanan minuman terjamin & 3,80 \\
\hline & Rata-rata & 3,84 \\
\hline B. & Harga & \\
\hline 6. & Harga bersaing & 4,02 \\
\hline 7. & Harga dapat dijangkau & 3,89 \\
\hline 8. & Jangka waktu pembayaran baik & 3,90 \\
\hline 9. & Harga yang menarik & 3,90 \\
\hline \multirow[t]{2}{*}{10.} & Harga minuman cocok dengan manfaat & 3,75 \\
\hline & Rata-rata & 3,89 \\
\hline C. & Saluran Distribusi & \\
\hline 11. & Pemesanan minuman mudah & 3,93 \\
\hline
\end{tabular}




\begin{tabular}{|c|c|c|}
\hline 12. & Minuman tersedia ketika diorder & 3,97 \\
\hline 13. & Minuman tidak rusak & 3,80 \\
\hline 14. & Proses kirim minuman cepat & 3,93 \\
\hline \multirow[t]{2}{*}{15 . } & Pegawai ramah dalam mengirim minuman & 3,75 \\
\hline & Rata-rata & 3,88 \\
\hline D. & Promosi & \\
\hline 16. & Konsep iklan minuman efektif & 3,86 \\
\hline 17. & Iklan tepat sasaran & 3,92 \\
\hline 18. & Pegawai meningkatkan pembelian minuman & 3,95 \\
\hline 19. & Iklan membuat minuman semakin dikenal & 3,86 \\
\hline \multirow[t]{4}{*}{20.} & Jargon membuat minuman dikenal & 3,65 \\
\hline & Rata-rata & 3,85 \\
\hline & Jumlah & 77,30 \\
\hline & Rerata & 3,86 \\
\hline
\end{tabular}

Sumber: Data olahan, 2020

Setelah diketahui hasil tanggapan responden mengenai rata-rata kinerja, maka dilakukan perhitungan nilai rata-rata dari rata-rata skor kinerja untuk semua variabel:

Kebijakan Produk $\quad:(3,71+3,95+3,92+3,82+3,80) / 5=3,84$

Kebijakan Harga $\quad:(4,02+3,89+3,90+3,90+3,75) / 5=3,89$

Kebijakan Distribusi : $(3,93+3,97+3,80+3,93+3,75) / 5=3,88$

Kebijakan Promosi $:(3,86+3,92+3,95+3,86+3,65) / 5=3,85$

TABEL 4. Analisis Peringkat Tingkat Kinerja

Terhadap Variabel Kebijakan Pemasaran Yakult

\begin{tabular}{lccc}
\hline \multicolumn{1}{c}{ Variabel Kebijakan Pemasaran } & Nilai & Bobot (\%) & Peringkat \\
\hline 1. Kebijakan Produk & 3,84 & 24,84 & 4 \\
2. Kebijakan Harga & 3,89 & 25,16 & 1 \\
3. Kebijakan Distribusi & 3,88 & 25,10 & 2 \\
4. Kebijakan Promosi & 3,85 & 24,90 & 3 \\
\multicolumn{1}{c}{ Total } & 15,46 & 100,00 & \\
\hline
\end{tabular}

Sumber: Data olahan, 2020

Dari Tabel 4, diketahui bahwa kebijakan harga menempati peringkat pertama dengan nilai 3,89 atau berbobot 25,16 persen dan yang menempati peringkat kedua adalah kebijakan distribusi dengan nilai 3,88 atau berbobot 25,10 persen. Peringkat ketiga ditempati oleh kebijakan promosi dengan nilai 3,85 atau berbobot 24,90 persen. Kemudian, posisi keempat ditempati kebijakan produk dengan nilai 3,84 atau berbobot 24,84 persen.

TABEL 5. Rata-Rata Tingkat Kepentingan Terhadap Variabel Kebijakan Pemasaran Yakult

\begin{tabular}{clc}
\hline No. & \multicolumn{1}{c}{ Pertanyaan } & $\begin{array}{c}\text { Rata-rata } \\
\text { Tingkat } \\
\text { Kepentingan }\end{array}$ \\
\hline A. & Produk & \\
1. & Merek minuman telah dikenal & 4,03 \\
2. & Minuman bermutu & 4,02 \\
3. & Desain kemasan minuman menarik & 3,98 \\
4. & Kemasan minuman produk yang bermutu & 3,87 \\
5. & Ketahanan minuman terjamin & 3,85 \\
& & 3,95 \\
B. & Hargatata & \\
6. & Harga bersaing & 4,04 \\
7. & Harga dapat dijangkau & 3,91 \\
8. & Jangka waktu pembayaran baik & 3,96 \\
\hline
\end{tabular}




\begin{tabular}{|c|c|c|}
\hline 9. & Harga yang menarik & 3,91 \\
\hline \multirow[t]{2}{*}{10.} & Harga minuman cocok dengan manfaat & 3,79 \\
\hline & Rata-rata & 3,92 \\
\hline C. & Saluran Distribusi & \\
\hline 11. & Pemesanan minuman mudah & 4,02 \\
\hline 12. & Minuman tersedia ketika diorder & 4,00 \\
\hline 13. & Minuman tidak rusak & 3,90 \\
\hline 14. & Proses kirim minuman cepat & 3,94 \\
\hline \multirow[t]{2}{*}{15.} & Pegawai ramah dalam mengirim minuman & 3,77 \\
\hline & Rata-rata & 3,93 \\
\hline D. & Promosi & \\
\hline 16. & Konsep iklan minuman efektif & 3,90 \\
\hline 17. & Iklan tepat sasaran & 3,99 \\
\hline 18. & Pegawai meningkatkan pembelian minuman & 4,01 \\
\hline 19. & Iklan membuat minuman semakin dikenal & 3,94 \\
\hline \multirow[t]{4}{*}{20.} & Jargon membuat minuman dikenal & 3,68 \\
\hline & Rata-rata & 3,90 \\
\hline & Jumlah & 78,50 \\
\hline & Rerata & 3,93 \\
\hline
\end{tabular}

Sumber: Data olahan, 2020

Setelah diketahui rata-rata kepentingan responden, maka dilakukan perhitungan nilai rata-rata dari rata-rata skor kepentingan untuk seluruh variabel, yaitu:

Kebijakan Produk $\quad:(4,03+4,02+3,98+3,87+3,85) / 5=3,95$

Kebijakan Harga $\quad:(4,04+3,91+3,96+3,91+3,79) / 5=3,92$

Kebijakan Distribusi : $(4,02+4,00+3,90+3,94+3,77) / 5=3,93$

Kebijakan Promosi $:(3,90+3,99+4,01+3,94+3,68) / 5=3,90$

Berikut ini adalah tanggapan responden mengenai tingkat kepentingan terhadap variabel kebijakan pemasaran:

TABEL 6. Analisis Peringkat Tingkat Kepentingan Terhadap Variabel Kebijakan Pemasaran

\begin{tabular}{cccc} 
& Yakult & & \\
\hline Variabel Kebijakan Pemasaran & Nilai & Bobot $(\boldsymbol{\%})$ & Peringkat \\
\hline 1. Kebijakan Produk & 3,95 & 25,16 & 1 \\
2. Kebijakan Harga & 3,92 & 24,97 & 3 \\
3. Kebijakan Distribusi & 3,93 & 25,03 & 2 \\
4. Kebijakan Promosi & 3,90 & 24,84 & 4 \\
Total & 15,70 & 100,00 & \\
\hline
\end{tabular}

Sumber: Data olahan, 2020

Dari Tabel 6, diketahui bahwa kebijakan produk menempati peringkat pertama dengan nilai 3,95 atau berbobot 25,16 persen dan yang menempati peringkat kedua adalah kebijakan distribusi dengan nilai 3,93 atau berbobot 25,03 persen. Peringkat ketiga ditempati oleh kebijakan harga dengan nilai 3,92 atau berbobot 24,97 persen. Kemudian, posisi keempat ditempati kebijakan promosi dengan nilai 3,90 atau berbobot 24,84 persen.

TABEL 7. Rekapitulasi Hasil Analisis Tingkat Kinerja, Tingkat Kepentingan Dan Tingkat Kesesuaian Variabel Kebijakan Pemasaran Yakult

\begin{tabular}{clccc}
\hline No. & \multicolumn{1}{c}{ Pertanyaan } & $\begin{array}{c}\text { Rata-rata } \\
\text { Tingkat } \\
\text { Kinerja }\end{array}$ & $\begin{array}{c}\text { Rata-rata } \\
\text { Tingkat } \\
\text { Kepentingan }\end{array}$ & $\begin{array}{c}\text { Tingkat } \\
\text { Kesesuaian } \\
(\%)\end{array}$ \\
\hline A. & Produk & & & \\
1. & Merek minuman telah dikenal & 3,71 & 4,03 & 92,06 \\
2. & Minuman bermutu & 3,95 & 4,02 & 98,26 \\
3. & Desain kemasan minuman menarik & 3,92 & 3,98 & 98,49 \\
4. & Kemasan minuman produk yang bermutu & 3,82 & 3,87 & 98,71 \\
\hline
\end{tabular}




\begin{tabular}{|c|c|c|c|c|}
\hline \multirow[t]{2}{*}{5.} & Ketahanan minuman terjamin & 3,80 & 3,85 & 98.70 \\
\hline & Rata-rata & 3,84 & 3,95 & 97,24 \\
\hline B. & \multicolumn{4}{|l|}{ Harga } \\
\hline 6. & Harga bersaing & 4,02 & 4,04 & 99,50 \\
\hline 7. & Harga dapat dijangkau & 3,89 & 3,91 & 99,49 \\
\hline 8. & Jangka waktu pembayaran baik & 3,90 & 3,96 & 98,48 \\
\hline 9. & Harga yang menarik & 3,90 & 3,91 & 99,74 \\
\hline \multirow{2}{*}{10.} & Harga minuman cocok dengan manfaat & 3,75 & 3,79 & 98,94 \\
\hline & Rata-rata & 3,89 & 3,92 & 99,23 \\
\hline C. & \multicolumn{4}{|l|}{ Saluran Distribusi } \\
\hline 11. & Pemesanan minuman mudah & 3,93 & 4,02 & 97,76 \\
\hline 12. & Minuman tersedia ketika diorder & 3,97 & 4,00 & 99,25 \\
\hline 13. & Minuman tidak rusak & 3,80 & 3,90 & 97,44 \\
\hline 14. & Proses kirim minuman cepat & 3,93 & 3,94 & 99,75 \\
\hline \multirow[t]{2}{*}{15.} & Pegawai ramah dalam mengirim minuman & 3,75 & 3,77 & 99,47 \\
\hline & Rata-rata & 3,88 & 3,93 & 98,73 \\
\hline D. & \multicolumn{4}{|l|}{ Promosi } \\
\hline 16. & Konsep iklan minuman efektif & 3,86 & 3,90 & 98,97 \\
\hline 17. & Iklan tepat sasaran & 3,92 & 3,99 & 98,25 \\
\hline 18. & Pegawai meningkatkan pembelian minuman & 3,95 & 4,01 & 98,50 \\
\hline 19. & Iklan membuat minuman semakin dikenal & 3,86 & 3,94 & 97,97 \\
\hline \multirow[t]{4}{*}{20.} & Jargon membuat minuman dikenal & 3,65 & 3,68 & 99,18 \\
\hline & Rata-rata & 3,85 & 3,90 & 98,57 \\
\hline & Jumlah & 77,30 & 78,50 & \\
\hline & Rerata & 3,86 & 3,93 & \\
\hline
\end{tabular}

Sumber: Data olahan, 2020

Untuk mengetahui bagaimana tingkat kesesuaian yang dicapai antara kinerja dan kepentingan konsumen pada setiap variabel kebijakan pemasaran dapat dilihat pada Tabel 7.

TABEL 8. Tingkat Kesesuaian Antara Kinerja Dan Kepentingan Pada Setiap Variabel Dalam Hubungan Dengan Kebijakan Pemasaran Yakult

\begin{tabular}{clc}
\hline No. & \multicolumn{1}{c}{ Variabel } & Tingkat Kesesuaian \\
\hline 1. & Produk (product) & 97,24 \\
2. & Harga (price) & 99,23 \\
3. & Salurand distribusi (place) & 98,73 \\
4. & Promosi (promotion) & 98,57 \\
\hline \multicolumn{2}{l}{ Sumber: Data olahan, 2020 }
\end{tabular}

Dari Tabel 8 diketahui bahwa tingkat kesesuaian antara kinerja dan kepentingan tiap variabel dalam hubungan dengan kebijakan pemasaran memiliki angka-angka lebih dari tingkat kesesuaian yang sangat sesuai, yang artinya tingkat kesesuaian telah memenuhi kepentingan konsumen.

\section{E. Simpulan dan Saran}

\section{Simpulan}

Peneliti menarik kesimpulan sebagai berikut:

Hasil perhitungan menunjukkan sangat sesuai, Produk (product) dengan nilai tingkat kesesuaian sebesar 97,24 persen, Harga (price) dengan nilai tingkat kesesuaian sebesar 99,23 persen, Saluran Distribusi (place) dengan nilai tingkat kesesuaian sebesar 98,73 persen, dan Promosi (promotion) dengan nilai tingkat kesesuaian sebesar 98,57 persen.

Tingkat kinerja kepentingan harga (price) kebijakan menempati peringkat pertama, kebijakan saluran distribusi (place) menempati peringkat kedua, Promosi (promotion) menempati peringkat ketiga, kebijakan produk menempati peringkat keempat. 


\section{Saran}

Beberapa saran sebagai berikut:

a. Kinerja Pengecer sudah sangat sesuai dengan harapan konsumen namun kinerja tersebut harus dipertahankan dan lebih ditingkatkan karena kinerjanya belum mencapai optimal. Untuk menjaga agar konsumen tetap setia dengan perusahaan, maka perusahaan perlu memperhatikan kebijakan harga agar lebih sesuai lagi dengan harapan konsumen, dan promosipromosi yang lebih menarik dapat dilakukan perusahaan dengan melalui media surat kabar, dengan pemberian penghargaan atau hadiah kepada pengecer yang dapat menjual produk dalam jumlah banyak

b. Selama ini, perusahaan jarang memberikan penghargaan ataupun hadiah kepada pengecer. Dengan promosi seperti ini diharapkan pengecer akan terpacu untuk berusaha melakukan penjualan yang lebih baik lagi dengan demikian jumlah penjualan akan menjadi lebih baik dan otomatis akan meningkatkan penjualan perusahaan, dan Melakukan inovasi produk dengan menambah rasa yang beragam untuk meningkatkan jumlah konsumen.

\section{Daftar Referensi}

Alma, Buchari. Manajemen Pemasaran dan Pemasaran Jasa. Bandung: Alfabeta, 2011.

Arikunto, Suharsimi. Prosedur Penelitian, edisi revisi kedelapan. Jakarta: PT Rineka Cipta, 2006.

Boyd, Harper W., Oville C. Walker, Jean-Claude Larreche. Manajemen Pemasaran: Suatu Pendekatan Strategis Dengan Orientasi Global. Jakarta: Erlangga, 2000.

Dharmmesta, Basu Swastha, dan Irawan. Manejemen Pemasaran Modern, edisi kedua. Yogyakarta: Liberty, 2008.

Fathoni, Abdurrahmat. Metodologi Penelitian dan Teknik Penyusunan Skripsi. Jakarta: PT Rineka Cipta, 2006.

Fuad, M., et al. Pengantar Bisnis. Jakarta: Gramedia Pustaka Utama, 2000.

Harga Yakult Eceran dan Pack Terbaru_Daftar Harga \& Tarif, Anang Panca, 4 April 2000, Harga, web.id.

http://erdyasyraf.blogspot.com/2018/11/sistem-produksi-pt.html

Kotler, Philip. Manajemen Pemasaran (Judul Asli: Marketing Management), edisi kesebelas, jilid 1. Penerjemah Benyamin Molan. Jakarta: Index, 2005.

Kotler, Philip, dan Kevin Lane Keller. Manajemen Pemasaran (Judul Asli: Marketing Management), edisi kedua belas, jilid 1. Penerjemah: Benyamin Molan. Jakarta: PT Indeks, 2008.

Kotler, Philip, dan Gary Armstrong. Prinsip-prinsip Pemasaran (Judul Asli: Principles of Marketing), jilid 1. Jakarta: Penerbit Erlangga, 2001.

Jakarta: Penerbit Indeks, 2004.

Dasar-dasar Pemasaran, edisi kesembilan, jilid 2.

Peter, J. Paul, dan Jerry C. Olson, Consumer Behavior: Perilaku Konsumen dan Strategi Pemasaran. Jakarta: Erlangga, 2000.

Sarwono, Jonathan. Metode Penelitian Kuantitatif dan Kualitatif. Yogyakarta: Penerbit Graha Ilmu, 2006.

Sugiyono. Metode Penelitian Kuantitatif, Kualitatif dan R\&D. Bandung: Alfabeta, 2012

Sudjarwo. Metodologi Penelitian Sosial. Bandung: CV Mandar Maju, 2001.

Tjiptono, Fandy, Pemasaran Jasa. Malang: Bayumedia, 2005. 